\title{
HUBUNGAN ANTARA GAYA KEPEMIMPINAN KARISMATIK KEPALA SEKOLAH DAN KEPRIBADIAN DENGAN KEINOVATIFAN GURU
}

\author{
Elis Sutianah $^{1}$, Widodo Sunaryo ${ }^{2}$, Adie E. Yusuf ${ }^{2}$ \\ ${ }^{1}$ Guru SMPN 2 Cicurug, Sukabumi, Jawa Barat \\ ${ }^{2}$ Program Pascasarjana Universitas Pakuan, \\ Email: pasca@unpak.ac.id
}

\begin{abstract}
The objective of this research is to analyze the correlation between The Charismatic Leadership Style and Personality with the Teacher's Innovation. This research uses two independent variables, those are The Charismatic Leadership Style and Personality with the Teacher's Innovation. The research was conducted at 15 states Junior High Schools at Cicurug Subdistrict Sukabumi West Java in 2017 with 130 samples selected from 193 of populations, selected by Proporsional Random Sampling. This research uses survey method by analyzing data with sample and multiple correlation statistic test. The research concludes that: First, there is positive and highly significant correlation between Charismatic Leadership Style (X1) and Teacher's Innovation. (Y) with regression equation $\hat{Y}=49,037+$ $0,603 X 1$ and correlation coefficient ryl $=0,7164$ and determination coefficient $r 2 y 1=$ 0,5132. Second; there was positive and highly significant correlation between Personality (X2) with Teacher's Innovation. with regression equation $\hat{Y}=46,384+0,634$ X2 and correlation coefficient ry $2=0,6989$ and determination coefficient $r 2 y 2=0,4884$; and the Third, there was positive highly significant correlation between Charismatic Leadership Style (X1) and Personality (X2) all together with Teacher's Innovation. (Y) with regression eqution $\hat{Y}=18,872+0,422 X_{1}+0,419 X 2$. correlation coefficient ry $12=0,8290$ and $r_{-}(y .12)^{\wedge} 2$ determination coefficient 0,6873, or it means that the contribution of pedagogical competencies and achivement motivation links to Teacher's Innovation. Based on the description above,teacher's innovation can be enhanced through Charismatic Leadership Style and Personality.
\end{abstract}

Keywords: Charismatic Leadership, Personality, Teacher Innovation

\begin{abstract}
ABSTRAK
Penelitian ini dapat digolongkan dalam penelitian korelasional yang terdiri atas dua variabel bebas yaitu Kepemimpinan Karismatik dan kepribadian serta satu variabel terikat yaitu keinovatifan guru. Penelitian dilaksanakan di 15 SMP Negri se-Komisariat Cicurug Kabupaten Sukabumi Propinsi Jawa Barat pada tahun 2017 dengan sampel 130 dari populasi 193 yang diambil secara Proporsional Random Sampling.Metode yang digunakan yaitu survai dan teknik analisis data menggunakan uji statistik korelasi dan regresi linier sederhana serta uji statistik korelasi dan regresi linier ganda. Hasil penelitian menghasilkan tiga kesimpulan yaitu, Pertama, terdapat hubungan positif dan sangat signifikan antara Kepemimpinan Karismatik (X1) dan Keinovatifan Guru (Y) yang dinyatakan dengan persamaan regresi $\hat{Y}=49,037+0,603 \mathrm{X} 1$ dan koefisien korelasi rx1y $=0,7164$ serta koefisien determinasi $\mathrm{r} 2 \mathrm{x} 1 \mathrm{y}$ sebesar 0,5132. Kedua, terdapat hubungan positif dan sangat signifikan antara variabel Kepribadian (X2) dengan Keinovatifan Guru (Y), yang dinyatakan dalam bentuk persamaan regresi $\hat{Y}=46,384+0,634 X 2$ dan koefisien korelasi $r$ sebesar 0,6989 serta kofisen determinasi $\mathrm{r} 2 \mathrm{x} 2 \mathrm{y}$ sebesar 0,4884 . Ketiga terdapat hubungan positif dan
\end{abstract}


sangat signifikan antara variabel Kepemimpinan Karismatik (X1) dan Kepribadian (X2) secara bersama-sama dengan Keinovatifan Guru (Y) yang dinyatakan dalam bentuk persamaan regresi $\hat{Y}=18,872+0,422 X_{1}+0,419 \mathrm{X} 2$ dan koefisien korelasi Rx1x2y sebesar 0,6873 serta koefisien determinasi R_y12^2 sebesar 0,6873. Berdasarkan hal-hal tersebut dapat disimpulkan bahwa Keinovatifan guru dapat ditingkatkan melalui Kepemimpinan Karismatik dan Kepribadian

Kata Kunci: Kepemimpinan Karismatik,Kepribadian, Keinovatifan Guru

\section{PENDAHULUAN}

Peningkatan mutu pendidikan ditentukan oleh kesiapan sumber daya manusia yang terlibat dalam proses pendidikan. Guru merupakan salah satu faktor penentu tinggi rendahnya mutu hasil pendidikan. Keberadaan guru sebagai garis terdepan dalam proses pendidikan dan pengajaran selalu disoroti oleh berbagai pihak yang merasakan dampak dari hasil pendidikan dimana guru berperan. Guru menurut UU no. 14 tahun 2005 adalah pendidik professional dengan tugas utama mendidik, mengajar, membimbing, mengarahkan, melatih, menilai, dan mengevaluasi peserta didik pada pendidikan anak usia dini jalur pendidikan formal, pendidikan dasar, dan pendidikan menengah.

Gaya kepemimpinan kepala sekolah yang berkarismatik dapat meningkatkan keinovatifan guru dalam tugas dan pekerjaan, karena kepalas ekolah sebagai pemimpin mengetahui dengan pasti dan yakin apa yang menjadi tujuan dari proses pendidikan, kepala sekolah dapat mempengaruhi seluruh warga sekolah untuk mencapai tujuan tersebut. Guru yang berinovatif akan mempengaruhi dalam kepemimpinan karismatik kepala sekolah, salah satu gaya kepemimpinan yang fenomena luntuk membentuk mutu pendidikan didimasa yang akan dating dengan membawa harapan menciptakan karya inovasi yang lebih baik.

\section{Keinovatifan Guru}

Mothersbaugh (2010:248) menyatakan bahwa inovasi adalah ide, hal-hal praktis atau produk yang diterima sebagai sesuatu hal yang baru oleh individu atau kelompok. Osbon (2014:342) mengatakan bahwa Inovasi adalah suatu proses pembentukan ide-ide baru dan meletakanya ke dalam pelatihan sebagai suatu proses dan bagian dari produk inovasi dan proses inovasi.

Jones (2012:24-25) mengatakan bahwa inovasi merupakan suatu kemampuan organisasi untuk membuat sesuatu hal baru dan peningkatan yang bagus ,dan pelayanan atau suatu cara meningkatkan yang mereka hasilkan. Schemerhorn (2010:376) mengemukakan bahwa inovasi adalah proses yang menghasilkan ide-ide baru yang diaplikasikan atau diterapkan. Ini berarti bahwa ide baru yang diaplikasikan setiap saat akan memberikan kontribusi yang dapat memperbaiki pelayanan terhadap masyarakat dan meningkatkan produktivitas organisasi.

Selanjutnya menurut Robbins (2013:626) inovasi adalah suatu ide/gagasan baru dalam penerapan pada inisiasi atau meningkatkan suatu hasil/produk, proses, dan pelayanan, Menurut Baron (2008:568) inovasi adalah aktivitas untuk meningkatkan dalam perubahan pada sesuatu yang siap di bangun dengan memperkenalkan sesuatu yang implementasi kesuksesanya pada ide-ide kreatif dalam sebuah organisasi.

Dari beberapa teori yang telah dikemukakan peneliti menyimpulkan bahwa keinovatifan guru adalah suatu kemampuan yang berorientasi untuk meningkatkan inovasi , sarana dan prasarana dalam jumlah tertentu untuk mencapai suatu tujuan, dengan indikator sebagai berikut (1) Produk inovasi, (2) Proses inovasi, (3) Pelayanan Inovasi. 


\section{Kepemimpinan Karismatik}

Menurut Gibson (2012:351-353) Kepemimpinan Karismatik adalah kualitas yang menonjol pada seseorang pemimpin dalam mempengaruhi pengikutnya dengan menggunakan anugrah supranatural dan kekuatan pengikutnya. Selanjutnya Gibson (2012:351-353) menjelaskan definisi Gaya Kepemimpinan Karismatik adalah kualitas pemimpin dalam mengidentifikasi secara tepat. Tuntutan -tuntutan, nilai-nilai dan harapanharapan pengikutnya dan kemudian ditransformasikan menjadi kepentingan semua.

Menurut Luthans (2011:428-429) Gaya Kepemimpinan Karismatik adalah kepemimpinan yang mempunyai pribadi yang mendalam dan efek luar biasa untuk memotivasi para pengikutnya dalam mencapai performa yang luar biasa.

Menurut Ivancevich (2002:351) gaya Kepemimpinan Karismatik adalah kepemimpinan menciptakan suasana motivasi berdasarkan komitmen emosional, dan identifikasinya dengan visi, filsafat, dan gaya pada pengikutnya. Robbins (2006:469) mengemukakan Gaya Kepemimpinan Karismatik adalah kepemimpinan yang heroik atau luar biasa yang memicu para pengikutnya ketika mengamati perilaku-perilaku pemimpinnya.

Menurut Herold (2009:410) Gaya Kepemimpinan Karismatik adalah berhubungan dengan perilaku pelaksanaan inovasi dan akibatnya diidentifikasikan konstruk kepemimpinan dalam mempromosikan yang memainkan peran penting dalam mempromosikan pengikutnya, Selanjutnya menurut Barron (2008:516) pemimpin karismatik adalah pemimpin yang member efek sangat kuat pada pengikutnya tentang mereka,seperti individu yang memiliki jumlah pada kepercayaan diri sendiri.

Menurut Judge (2003:341-342) Gaya Kepemimpinan Karismatik adalah teori kepemimpinan yang menyatakan bahwa pengikut membuat attriibusi dari kemampuan kepemimpinan heroik atau luar biasa ketika mereka mengamati perilaku tertentu. Sedangkan menurut Wood (2001:470) gaya Kepemimpinan Karismatik adalah kepemimpinan yang melalui kekuatan pada kemampuan individunya.

Dari semua teori yang di kemukakan di atas peneliti simpulkan bahwa Gaya Kepemimpinan Karismatik adalah sikap seorang pemimpin yang mempunyai kualitas pribadi yang kuat dan memberikan efek yang luar biasa pada pengikutnya ,dengan memiliki orientasi kekuasaan yang sosial dengan cara menekankan internalisasi dari nilai nilai bukan identifikasi pribadi serta keyakinan yang dimiliki individu untuk mencapai performa yang luar biasa.

\section{Kepribadian}

Menurut Pendapat Gibson (2006:113-117) kepribadian adalah seperangkat karakteristik relative stabil, kecenderungan dan telah dibicarakan secara signifikan membentuk suatu factor social, budaya, dan lingkungan. Sedangkan menurut Colquit, (2011:294-296) kepribadian mengacu pada struktur dan kecenderungan seseorang yang menjelaskan tentang karekteristik mereka, berpikir, emosi, dan perilaku.

Selanjutnya menurut Kreitner (2008:133) kepribadian dapat didefinisikan sebagai kombinasi dari karakteristik fisik, dan mental yang stabil yang memberikan individu dan identitasnya. Menurut Colquitt (2009:294-295) Kepribadian adalah didorong oleh alam atau pengasuhan yang bisa kita ketahui.

Selanjutnya Slocum (2011:70) mengemukakan kepribadian adalah sesuatu yang memperlihathatkan kualitas unik pada seseorang atau individu. Menurut Stephen P. Robbins Kepribadian adalah jumlah total cara dimana seorang individu bereaksi dan berinteraksi dengan orang lain.

Menurut Baron (2008:135-142) kepribadian adalah pola unik dan relatif stabil prilaku, pikiran, dan emosi yang di tunjukan oleh individu. Selanjutnya Robbins juga 
mengungkapkan kembali bahwa kepribadian adalah suatu karakteristik manusia yang lebih menekankan pada sikap dan prilaku seseorang.

Dari kajian beberapa teori yang diungkapkan oleh para ahli di atas, maka epribadian itu adalah seperangkat karakteristik yang dimiliki seseorang yang relative stabil, cenderung di pengaruhi oleh faktor social, budaya, dan faktor lingkungan. (1) Ekspresi (2) Keramahan (3) Sifat berhati-hati (4) Stabilitas emosi. (5) Keterbukaan pada pengalaman.

\section{METODE PENELITIAN}

Penelitian ini akan dilaksanakan di SMPN sekomisariat Cicurug Kabupaten Sukabum Jawa Barat 13 SMP Negeri. Penelitian ini akan dilaksanakan mulai bulan april 2017 sampai bulan Mei tahun 2017. Metode yang digunakan dalam penelitian ini adalah survey dengan pendekatan korelasional, sebagai metode kuantitatif yang memenuhi kaidah-kaidah ilmiah yaitu konkrit/empiris, objektif, terukur, rasional, dan sistematis.

Populasi penelitian ini adalah seluruh guru PNS SMP Se-komisariat Cicurug Kabupaten Sukabumi Provinsi Jawa Barat sebanyak 193 guru, dengans sampel sebanyak 130 responden.

\section{HASIL PENELITIAN}

\section{Pengujian Persyaratan Analisis}

\section{Uji Normalitas}

Berdasarkan perhitungan uji normalitas galat baku taksiran $\left(\mathrm{Y}-\hat{\mathrm{Y}}_{1}\right)$ persamaan regresi antara variabel Gaya Kepemimpinan Karismatik Kepala Sekolah $\left(\mathrm{X}_{1}\right)$ dengan variabel Inovasi Guru (Y), diperoleh nilai terbesar luas daerah $\left(\mathrm{L}_{0 \max }\right)$ sebesar 0,0388 , sementara $\mathrm{L}_{\text {tabel }}$ untuk $\mathrm{n}=130$ dan taraf signifikansi $=0,05$ sebesar 0,0864. Persyaratan galat baku berdistribusi normal adalah jika $\mathrm{L}_{0}<\mathrm{L}_{\mathrm{t}}$. Dengan demikian, galat baku taksiran $\left(\mathrm{Y}-\hat{\mathrm{Y}}_{1}\right)$ persamaan regresi antara variabel Kepemimpinan Karismatik Kepala Sekolah $\left(\mathrm{X}_{1}\right)$ dengan variabel Keinovatifan Guru (Y) berasal dari populasi yang berdistribusi normal, karena $\mathrm{L}_{0}$ sebesar 0,0388 < $\mathrm{L}_{\mathrm{t}}$ sebesar 0,0864 pada taraf kepercyaan $\alpha=0,05$ dan $\mathrm{n}=130$.

Berdasarkan perhitungan uji normalitas galat baku taksiran $\left(\mathrm{Y}-\hat{\mathrm{Y}}_{2}\right)$ persamaan regresi variabel Kepribadian $\left(\mathrm{X}_{2}\right)$ dengan variabel Keinovatifan Guru (Y), diperoleh nilai terbesar luas daerah $\left(\mathrm{L}_{0 \text { maks }}\right)=0,0790$, sementara sementara $\mathrm{L}_{\text {tabel }}$ untuk $\mathrm{n}=130$ dan taraf signifikansi $=0,05$ sebesar 0,0864. Persyaratan galat baku berdistribusi normal adalah jika $\mathrm{L}_{0}<\mathrm{L}_{\mathrm{t}}$. Dengan demikian, galat baku taksiran $\left(\mathrm{Y}-\hat{\mathrm{Y}}_{2}\right)$ persamaan regresi antara variabel Kepribadian $\left(\mathrm{X}_{2}\right)$ dengan variabel Keinovatifan Guru $(\mathrm{Y})$ berasal dari populasi yang berdistribusi normal, karena $\mathrm{L}_{0}$ sebesar $0,0790<\mathrm{L}_{\mathrm{t}}$ sebesar 0,0864 pada taraf kepercyaan $\alpha=$ 0,05 dan $\mathrm{n}=130$.

\section{Uji Homogenitas}

Berdasarkan hasil perhitungan, homogenitas data Keinovatifan Guru atas Gaya Kepemimpinan Karismatik Kepala Sekolah diperoleh nilai $\chi_{\text {hitung }}^{2}=42,463$, sedangkan $\chi_{\text {tabel }}^{2}$ untuk $\mathrm{dk}=83$ dan taraf signifikansi $=0,05$ sebesar $=64,011$, Persyaratan varians homogen adalah jika $\chi_{\text {hitung }}^{2}<\chi_{\text {tabel. }}^{2}$ Dengan demikian, varians data variabel Keinovatifan Guru (Y) atas variabel Gaya Kepemimpinan Karismatik Kepala Sekolah $\left(\mathrm{X}_{1}\right)$ berasal dari populasi

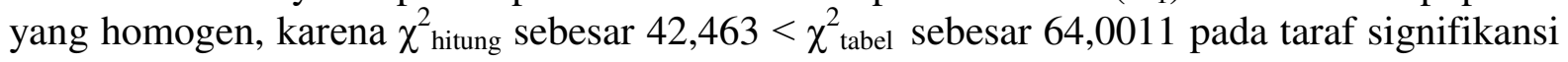
$=0,05$ dengan $\mathrm{dk}=83$.

Berdasarkan hasil perhitungan, homogenitas data Keinovatifan Guru atas Kepribadian diperoleh nilai $\chi_{\text {hitung }}^{2}=46,872$ sedangkan $\chi_{\text {tabel }}^{2}$ untuk dk $=82$ dan taraf signifikansi $=0,05$ sebesar $=65,1708$, Persyaratan varians homogen adalah jika $\chi_{\text {hitung }}^{2}<\chi_{\text {tabel. }}^{2}$ Dengan demikian, varians data variabel Keinovatifan Guru $(\mathrm{Y})$ atas variabel Kepribadian $\left(\mathrm{X}_{2}\right)$ berasal 
dari populasi yang homogen, karena $\chi_{\text {hitung }}^{2}$ sebesar $46,872<\chi_{\text {tabel }}^{2}$ sebesar 65,1708 pada taraf signifikansi $=0,05$ dengan $\mathrm{dk}=82$.

\section{Pengujian Hipotesis}

\section{Hubungan antara variabel Gaya Kepemimpinan Karismatik (X1) dengan Keinovatifan Guru (Y)}

Berdasarkan perhitungan regresi, Uji signifikansi regresi menunjukkan bahwa $F_{\text {hitung }}$ regresi $=318,336$, sedangkan $\mathrm{F}_{\text {tabel }}$ untuk dk 1:128 (pembilang $=1$ dan penyebut $=128$ ) dengan taraf signifikansi $0,05=3,915$, dan taraf signifikansi $0,01=6,837$. Hal ini menunjukkan bahwa $F_{\text {hitung }}>F_{\text {tabel }}$. Syarat signifikan adalah jika $F_{\text {hitung }}>F_{\text {tabel. }}$ Sehingga persamaan regresi antara variabel Kepemimpinan Karismatik Kepala Sekolah $\left(\mathrm{X}_{1}\right)$ dengan variabel Inovasi Guru $(\mathrm{Y})$ yang ditunjukkan oleh persamaan $\hat{\mathrm{Y}}=22,6184+0,8460 \mathrm{X}_{1}$, bersifat sangat signifikan $\left(F_{h}=318,336>6,837=F_{t}(\alpha=0,01)\right.$. Dengan demikian, hipotesis nol $\left(\mathrm{H}_{0}\right)$ ditolak dan hipotesis alternatif $\left(\mathrm{H}_{1}\right)$ diterima. Artinya, terdapat hubungan positif yang sangat signifikan antara Gaya Kepemimpinan Karismatik Kepala Sekolah dengan Inovasi Guru. hubungan fungsional antara Gaya Kepemimpinan Karismatik Kepala Sekolah $\left(\mathrm{X}_{1}\right)$ dengan Keinovatifan Guru $(\mathrm{Y})$ diperoleh persamaan regresi sebagai berikut: $\hat{\mathrm{Y}}=$ $22,6184+0,8460 \mathrm{X}_{1}$.

\section{Hubungan variabel Kepribadian $\left(\mathbf{X}_{2}\right)$ dengan Keinovatifan Guru (Y)}

Uji signifikansi regresi menunjukkan bahwa $F_{\text {hitung }}$ regresi $=109798$, sedangkan $F_{\text {tabel }}$ untuk dk 1: 128 (pembilang $=1$ dan penyebut $=128$ ) dengan taraf signifikansi $0,05=$ 3,915 , dan taraf signifikansi $0,01=6,837$. Hal ini menunjukkan bahwa $F_{\text {hitung }}>F_{\text {tabel }}$. Syarat signifikan adalah jika $F_{\text {hitung }}>F_{\text {tabel }}$. Sehingga persamaan regresi antara variabel Kepribadian $\left(\mathrm{X}_{2}\right)$ dengan variabel Keinovatifan Guru $(\mathrm{Y})$ yang ditunjukkan oleh persamaan $\hat{\mathrm{Y}}=67,9879$ $+0,4891 \mathrm{X}_{2}$ bersifat sangat signifikan $\left(\mathrm{F}_{\mathrm{h}}=109,798>6,837=\mathrm{F}_{\mathrm{t}(\alpha=0,01)}\right)$. Dengan demikian, hipotesis nol $\left(\mathrm{H}_{0}\right)$ ditolak dan hipotesis alternatif $\left(\mathrm{H}_{1}\right)$ diterima. Artinya, terdapat hubungan positif yang sangat signifikan antara Kepribadian dengan Keinovatifan Guru.

Uji linieritas sebagai salah satu persyaratan untuk menggunakan korelasi Product Moment Pearsons menunjukkan bahwa $\mathrm{F}_{\text {hitung }}$ tuna cocok $=1,517$, sedangkan $\mathrm{F}_{\text {tabel }}$ untuk $\mathrm{dk}$ $46: 82$ (pembilang $=46$ dan penyebut $=82$ ) dengan taraf signifikansi $0,05=1,517$. Hal ini

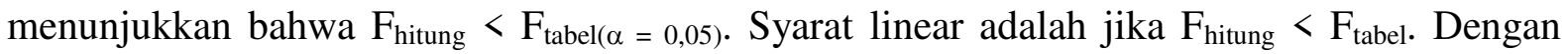
demikian, korelasi Product Moment Pearson dapat digunakan. Berdasarkan hasil perhitungan koefisien korelasi, diperoleh nilai koefisien korelasi $\left(\mathrm{r}_{\mathrm{y} 2}\right)$ sebesar 0,4637 dan nilai koefisien determinasi $\left(\mathrm{r}_{\mathrm{y} 1}^{2}\right)$ sebesar 0,2150 Hal ini menunjukkan bahwa 21,50\% variabel Keinovatifan Guru dapat diterangkan oleh varibale Kepribadian.

\section{Hubungan antara Gaya Kepemimpina Karismatik (X1) dan Kepribadian (X2) dengan Keinovatifan Guru (Y)}

Hubungan fungsional antara Gaya Kepemimpinan Karismatik Kepala Sekolah $\left(\mathrm{X}_{1}\right)$ dan Kepribadian $\left(\mathrm{X}_{2}\right)$ secara bersama-sama dengan Keinovatifan Guru (Y) dapat disajikan dalam bentuk persamaan regresi sebagai berikut $\hat{Y}=25,1809+0,9229 X_{1}+-0,0965 \mathrm{X}_{2}$. Uji signifikansi regresi ganda menunjukkan bahwa $F_{\text {hitung }}=139,58$, sedangkan $F_{\text {tabel }}$ untuk db 2 : 127 (pembilang $=2$ dan penyebut $=127$ ) dengan taraf signifikansi 0,05 $=3,068$, dan taraf signifikansi $0,01=4,776$. Hal ini menunjukkan bahwa $F_{\text {hitung }}>F_{\text {tabel. }}$. Syarat signifikan adalah jika $F_{\text {hitung }}>F_{\text {tabel. }}$. Sehingga regresi ganda antara variabel Gaya Kepemimpinan Karismatik Kepala Sekolah $\left(\mathrm{X}_{1}\right)$ dan Kepribadian $\left(\mathrm{X}_{2}\right)$ secara bersama-sama dengan variabel 
Keinovataifan Guru (Y) yang ditunjukkan oleh persamaan $\hat{Y}=9,7141+0,4678 X_{1}+0,4633$ $\mathrm{X}_{2}$ bersifat sangat signifikan $\left(\mathrm{F}_{\mathrm{h}}=39,031>4,776=\mathrm{F}_{\mathrm{t}(\alpha=0,01)}\right)$.

Berdasarkan hasil perhitungan koefisien korelasi, kekuatan hubungan antara variabel Gaya Kepemimpinan Karismatik Kepala Sekolah $\left(\mathrm{X}_{1}\right)$ dan variabel Kepribadian $\left(\mathrm{X}_{2}\right)$ secara bersama-sama dengan variabel Keinovatifan Guru $(\mathrm{Y})$ adalah $\mathrm{R}=0,7184$, dan nilai koefisien determinasi $\left(\mathrm{R}^{2}\right)$ sebesar 0,5160 Hal ini menunjukkan bahwa 51,60 \% variabel Inovasi Guru dapat diterangkan oleh baik variabel Gaya Kepemimpinan Karismatik Kepala Sekolah dan variabel Kepribadian.

Uji signifikansi koefisien korelasi ganda menunjukkan bahwa $f_{\text {hitung }}=78,3706$ sedangkan $f_{\text {tabel }}$ pada taraf signifikansi $0,05=3,080$ dan taraf signifikansi $0,01=4,805$. Hal ini menunjukkan bahwa $f_{\text {hitung }}>f_{\text {tabel }}$. Syarat signifikan adalah jika $f_{\text {hitung }}>f_{\text {tabel }}$. Sehingga korelasi antara variable Gaya Kepemimpinan Karismatik Kepala Sekolah $\left(\mathrm{X}_{1}\right)$ dan Kepribadian $\left(\mathrm{X}_{2}\right)$ secara bersama-sama dengan Keinovatifan Guru.(Y) adalah sangat signifikan $\left(\mathrm{f}_{\mathrm{h}}=78,376>4,805=\mathrm{f}_{\mathrm{t}(\alpha=0,01)}\right)$. Dengan demikian, hipotesis nol $\left(\mathrm{H}_{0}\right)$ ditolak dan hipotesis alternatif $\left(\mathrm{H}_{1}\right)$ diterima. Artinya, Terdapat hubungan positif antara Gaya Kepemimpinan Karismatik Kepala Sekolah dan Kepribadian secara bersama-sama dengan Keinovatifan Guru.

\section{Uji Korelasi Parsial}

Berdasarkan hasil perhitungan, koefisien korelasi $\mathrm{X}_{1}$ dengan $\mathrm{Y}$ jika $\mathrm{X}_{2}$ dikontrol diperoleh nilai $\mathrm{r}_{\mathrm{y} .12}=0,6193$. Untuk menguji tingkat signifikansi koefisien korelasi parsial yang dikontrol oleh variabel $\mathrm{X}_{2}$ dilakukan dengan uji t. Berdasarkan hasil perhitungan, diperoleh nilai $t_{\text {hitung }}=9,6593$, sedangkan $t_{\text {tabel }}$ pada taraf signifikansi $0,05=1,982$ dan taraf signifikansi $0,01=2,622$. Hal ini menunjukkan bahwa $t_{\text {hitung }}>t_{\text {tabel }}$. Syarat signifikan adalah jika $t_{\text {hitung }}>t_{\text {tabel }}$. Dengan demikian, korelasi antara variabel Gaya Kepemimpinan Karismatik Kepala Sekolah $\left(\mathrm{X}_{1}\right)$ dengan keinovatifan Guru (Y) dimana nilai $\mathrm{X}_{2}$ (variabel Kepribadian) dikontrol atau tetap adalah sangat signifikan $\left(\mathrm{t}_{\mathrm{h}}=9,6593>2,622=\mathrm{t}_{\mathrm{t}(\alpha=0,01)}\right)$ dengan kontribusi sebesar 0,3853 (38,35\%).

Koefisien korelasi $\mathrm{X}_{2}$ dengan $\mathrm{Y}$ jika $\mathrm{X}_{1}$ dikontrol diperoleh nilai $\mathrm{r}_{\mathrm{y} .21}=0,0920$. Untuk menguji tingkat signifikansi dari koefisien korelasi parsial antara $\mathrm{X}_{2}$ dengan $\mathrm{Y}$ yang dikontrol oleh variabel $\mathrm{X}_{1}$ dilakukan dengan uji $\mathrm{t}$. Berdasarkan hasil perhitungan, diperoleh nilai $\mathrm{t}_{\text {hitung }}=$ 1,1318 sedangkan $t_{\text {tabel }}$ pada taraf signifikansi $0,05=1,983$ dan taraf signifikansi $0,01=$ 2,622 . Hal ini menunjukkan bahwa $t_{\text {hitung }}>t_{\text {tabel. }}$. Syarat signifikan adalah jika $t_{\text {hitung }}>t_{\text {tabel }}$.

Dengan demikian, korelasi antara variabel Kepribadian $\left(\mathrm{X}_{2}\right)$ dengan Keinovatifan Guru (Y) dimana nilai $\mathrm{X}_{1}$ (variabel Gaya Kepemimpinan Karismatik Kepala Sekolah) dikontrol atau tetap adalah sangat signifikan $\left(\mathrm{t}_{\mathrm{h}}=1,1318>2,622=\mathrm{t}_{\mathrm{t}(\alpha=0,01)}\right)$ dengan kontribusi sebesar $0,0085(00, \%)$.

\section{PEMBAHASAN}

\section{Hubungan antara Gaya Kepemimpinan Karismatik Kepala Sekolah $\left(\mathbf{X}_{1}\right)$ dengan Keinovatifan Guru (Y)}

Untuk menguji hipotesis bahwa terdapat hubungan positif antara variabel $\mathrm{X}_{1}$ dengan variabel Y diperlukan uji signifikansi koefisien korelasi yaitu dengan uji t. Kriteria pengujian signifikansi koefisien korelasi adalah jika $t_{\text {hitung }}>t_{\text {tabel, }}$ maka koefisien korelasi dinyatakan signifikan. Berdasarkan hasil perhitungan diperoleh $t_{\text {hitung }}=11,5410$ sedangkan $t_{\text {tabel }}=1,979$ $(\mathrm{n}=130$ dan $\alpha=0,05)$, dan $\mathrm{t}_{\text {tabel }}=2,615(\mathrm{n}=130$ dan $\alpha=0,01)$ berarti koefisien korelasi antara Kepemimpinan Karismatik Kepala Sekolah $\left(\mathrm{X}_{1}\right)$ dengan Keinovatifan Guru (Y) adalah sangat signifikan. Dengan demikian, hipotesis nol $\left(\mathrm{H}_{0}\right)$ ditolak dan hipotesis alternatif $\left(\mathrm{H}_{1}\right)$ 
diterima. Artinya, terdapat hubungan positif yang sangat signifikan antara Gaya Kepemimpinan Karismatik Kepala Sekolah dengan Keinovatifan Guru.

Kekuatan hubungan antara Gaya Kepemimpinan Karismatik Kepala Sekolah dengan keinovatifan Guru ditunjukkan dengan koefisien korelasi $\left(\mathrm{r}_{\mathrm{y} 1}\right)$ sebesar 0,7155 dan koefisien determinasi $\left(\mathrm{r}_{\mathrm{y} 2}^{2}\right)$ sebesar 0,5119. Hal ini berarti bahwa 51,19\% variabel Keinovatifan Guru dapat dihasilkan dari adanya variabel Gaya Kepemimpinan Karismatik Kepala Sekolah.

Mengacu pada sudut pandang sintesis teori yang melandasi penelitian dinyatakan bahwa Gaya Kepemimpinan Karismatik Kepala Sekolah adalah prilaku seorang pemimpin yang mempunyai kualitas pribadi yang kuat dan memberikan efek yang luar biasa pada pengikutnya ,dengan memiliki orientasi kekuasaan yang sosial dengan cara menekankan internalisasi dari nilai nilai bukan identifikasi pribadi serta keyakinan yang dimiliki individu untuk mencapai performa yang luar biasa. Sintesis teori di atas juga merujuk dan mempertimbangkan pandangan Gibson (2006:113-117) yang mengemukakan tentang kepemimpinan karismatik adalah kepemimpinan yang mempunyai pribadi yang mendalam dan efek luar biasa untuk memotivasi para pengikutnya dalam mencapai performa yang luar biasa. Hal ini dapat di rasakan dalam kepemimpinan dalam lingkungan pendidikan.

Kepemimpinan karismatik merupakan perilaku seorang pemimpin yang mempunyai kualitas pribadi yang kuat dan memberikan efek yang luar biasa pada pengikutnya dengan memiliki kekuasaan yang social dengan cara menekankan internalisasi dari nilai nilai bukan identifikasi pribadi serta keyakinan yang dimiliki individu untuk mencapai performa yang luar biasa.

\section{Hubungan antara Kepribadian $\left(\mathbf{X}_{2}\right)$ dengan Keinovatifan Guru (Y)}

Untuk menguji hipotesis bahwa terdapat hubungan positif antara variabel $\mathrm{X}_{2}$ dengan variabel Y diperlukan uji signifikansi koefisien korelasi yaitu dengan uji t. Kriteria pengujian signifikansi koefisien korelasi adalah jika $t_{\text {hitung }}>t_{\text {tabel, }}$ maka koefisien korelasi dinyatakan signifikan. Berdasarkan hasil perhitungan diperoleh $t_{\text {hitung }}=5,9670$ sedangkan $t_{\text {tabel }}=1,979(\mathrm{n}$ $=130$ dan $\alpha=0,05)$, dan $t_{\text {tabel }}=2,615(\mathrm{n}=130$ dan $\alpha=0,01)$ berarti koefisien korelasi antara Kepribadian $\left(\mathrm{X}_{2}\right)$ dengan Keinofatifan Guru $(\mathrm{Y})$ adalah sangat signifikan. Dengan demikian, hipotesis nol $\left(\mathrm{H}_{0}\right)$ ditolak dan hipotesis alternatif $\left(\mathrm{H}_{1}\right)$ diterima. Artinya, terdapat hubungan positif yang sangat signifikan antara Kepribadian dengan Keinovatifan Guru.

Dari sudut pandang sintesis teori yang melandasi penelitian dinyatakan bahwa yang dimaksud dengan Kepribadian merupakan seperangkat karakteristik yang dimiliki seseorang yang relative stabil ,cenderung di pengaruhi faktor social,budaya,dan faktor lingkungan,dengan demikian peranan seseorang kepala sekolah dapat mempengaruhi upaya dalam pembinaan guru agar guru dapat meningkatkan kualitas mengajarnya dengan melalui langkah-langkah perencanaan, penampilan mengajar yang nyata serta mengadakan perubahan dengan cara yang rasional dalam usaha meningkatkan hasil belajar siswa melalui keinovasian guru

Sejalan dengan penelitian yang di tulis oleh Nuryahya (2011) bahwa Hubungan antara Kepribadian dengan Keinovatifan Guru mengandung arti bahwa salah satu tugas kepala sekolah adalah sebagai supervisor, yaitu mensupervisi pekerjaan yang dilakukan oleh guru. Jika kepala sekolah sebagai supervisor dapat melakukan tugas, fungsi dan tanggung jawabnya dengan baik melaksanakan supervisi terhadap guru secara efektif dan profesional maka pemberian supervisi oleh kepala sekolah tersebut akan meningkatkan keinovasian Guru. Hellriegel (2008:516) mengemukakan kepribadian merupakan sesuatu yang memperlihatkan kualitas unik pada seseorang atau individu . dengan mengacu pada factor stabilitas emosional ,keramahan, extraversi, sifat berhati-hati, kegelisahan, serta keterbukaan pada pengalaman. 


\section{Hubungan Antara Gaya Kepemimpinan Karismatik Kepala Sekolah dan Kepribadian Secara Bersama-sama dengan keinovatifan Guru}

Menguji hipotesis bahwa terdapat hubungan positif antara variabel Gaya Kepemimpinan Karismatik Kepala Sekolah $\left(\mathrm{X}_{1}\right)$ dan Kepribadian $\left(\mathrm{X}_{2}\right)$ dengan Keinovatifan Guru (Y) diperlukan uji signifikansi yaitu dengan uji F. Kriteria pengujian signifikan koefisien korelasi ganda adalah jika $\mathrm{F}_{\text {hitung }}>\mathrm{F}_{\text {tabel, }}$ maka koefisien korelasi ganda adalah sangat signifikan. Berdasarkan hasil perhitungan diperoleh $\mathrm{F}_{\text {hitung }}=78,3706$ sedangkan $\mathrm{F}_{\text {tabel }}$ $=3,080(\mathrm{dk}$ pembilang $=2$, dk penyebut $=127$, dan $\alpha=0,05)$, dan $F_{\text {tabel }}=4,776(\mathrm{dk}$ pembilang $=2$, dk penyebut $=127$, dan $\alpha=0,01$ ) berarti koefisien korelasi antara Gaya Kepemimpinan Karismatik Kepala Sekolah $\left(\mathrm{X}_{1}\right)$ dan Kepribadian $\left(\mathrm{X}_{2}\right)$ dengan KIeinovatifan Guru (Y) adalah sangat signifikan. Dengan demikian, hipotesis nol $\left(\mathrm{H}_{0}\right)$ ditolak dan hipotesis alternatif $\left(\mathrm{H}_{1}\right)$ diterima. Artinya terdapat hubungan positif yang sangat signifikan antara Gaya Kepemimpinan Karismatik Kepala Sekolah dan Kepribadian secara bersama-sama dengan Keinovatifan Guru.

Menurut Robbins (2013:626) juga mengungkapkan kembali bahwa kepribadian adalah karakteristik manusia yang lebih menekankan pada sikap dan prilaku seseorang dengan faktor sebagai berikut (1) Extraversi (2) Keramahan (3) Kehati-hatian (4) Stabiltas emosional (5) keterbukaan pada pengalaman.

Pada intinya banyak faktor pendukung yang dapat meningkatkan keinovatian Guru. Keinovatifan Guru terjadi karena adanya dorongan-dorongan dalam diri, dorongan-dorongan tersebut memerlukan tindakan yang didasari oleh kesadaran diri setiap individu. Dengan adanya kestabilan emosi akibat terpenuhinya Gaya Kepemimpinan Karismatik Kepala Sekolah dan ditambah pelaksanaan Kepribadian Guru sebagai salah satu faktor pendukung yang baik, maka secara optimal.akan meningkatkan keinovasian guru.

\section{SIMPULAN}

Berdasarkan penelitian ini dapat disimpulkan: (1) Penelitian ini menemukan hubungan positif dan sangat signifikan antara Kepemimpinan Karismatik Kepala Sekolah dengan Inovasi Guru yang dinyatakan dengan koefisien korelasi ryl $=0,7155(\alpha=0,05)$ dan didukung persamaan regresi $\hat{Y}=22,6184+0,8460$ X1 serta koefisien determinasi $\mathrm{r} 2 \mathrm{y} 1=$ 0,5119; (2) Penelitian ini menemukan hubungan positif dan sangat signifikan antara Kepribadian Guru dengan Inovasi Guru yang dinyatakan dengan koefisien korelasi ry2 = $0,6989(\alpha=0,05)$ dan didukung persmaan regresi $\hat{Y}=67,9879+0,4891$ X2 diperoleh nilai koefisien korelasi (ry2) sebesar 0,4637 dan koefisien diterminasi r2y2 =0,2150; dan (3) Penelitian ini juga menemukan hubungan positif dan sangat signifikan antara Gaya Kepemimpinan Karismatik Kepala Sekolah dan Kepribadian secara bersama-sama dengan Keinovatifan Guru yang dinyatakan dengan koefisien korelasi ry12 = 0,7184 didukung dengan persamaan regresi $\hat{Y}=25,1809+0,9229 X_{1}+-0,0965 X_{2}$ serta koefisien deterrminasi $\mathrm{R} 2=0,5160$.

\section{DAFTAR PUSTAKA}

Gibson, James L., John M. Ivancevich, dan James H. Donnelly, Jr., Organisasi: Perilaku, Struktur, dan Proses, Jilid 1, Terjemahan: Nunuk Adiarni, Tangerang: Binarupa Aksara, 2007.

Gibson, James L., John M. Ivancevich, James H. Donnelly, dan Konopaske, Organizations: Behavior,Structure, Processes, New York: McGraw-Hill/Irwin, 2009. 
Hawkins, Del I. and David L. Mothersbaugh. Consumer Behavior ,Building Marketing Strategy. New York: McGraw-Hill, 2010.

Husein Umar, Desain Penelitian MSDM dan Perilaku Karyawan: Paradigma Positivistik dan Berbasis Pemecahan Masalah, Jakarta: PT Raja Grafindo Persada, 2008.

Luthans, Fred, Organizational Behavior, Tent Edition, New York: McGraw-Hill Irwin, 2005.

McShane, Steven L. and Mary Ann Von Glinow, Organizational Behavior: Emerging Knowledge and Pracice for the Real World, Fith Edition, (New York: McGraw-Hill Irwin, 2010.

, Organizational Behavior, $5^{\text {th }}$ Edition, New York: McGraw-Hill/Irwin, 2010.

Nuryahya, Hubungan antara Kepemimpinan Transformasional Kepala Sekolah Budaya Organisasi dengan Kepuasan Kerja Guru di Lingkungan SMA Negeri Kota Sukabumu, Tesis: Universitas Pakuan, Bogor, 2011

Robbins, Stephen P., Essensials of Organizational Behavior, Third Edition, New Jersey: Prentice-Hall, Inc, 2009.

Robbins, Stephen P. dan Timothy A. Judge, Perilaku Organisasi: Organizational Behavior, Terjemahan; Diana Angelica, New Jersey: Pearson Education, 2007.

Schermerhorn, John R., James G. Hunt, Richard N. Osborn, Mary Uhl-Bien. Organizational Behavior. Hoboken: John Wiley \& Son, Inc., 2010.

Sedarmayanti, Manajemen Sumber Daya Manusia: Reformasi Birokrasi dan Manajemen Pegawai Negeri Sipil, Edisi Kelima, Bandung: PT Refika Aditama, 2011.

Wawan Nirwana, Hubungan antara Kepemimpinan Kepala Sekolah dan Motivasi Berprestasi dengan Kepuasan Kerja Guru SMPN di Kecamatan Rangkasbitung, Kabupaten Lebak, Tesis: Universitas Pakuan, Bogor, 2011

Wood, Wallace, Zeffane, Schermerhorn, Hunt, and Osborn, Organizational Behavior: A Global Perspective, Australia: John Wiley \& Sons, 2001.

Yukl, Gary, Kepemimpinan Kepala Sekolah dalam Organisasi, Edisi Kelima, Terjemahan: Budi Suprianto, Jakarta: PT Indeks, 2005. 